Gut, 1982, 23, 49-57

\title{
Fat absorption in germ-free and conventional rats artificially deprived of bile secretion
}

\author{
Y DEMARNE, T CORRING, ANDREE PIHET, AND E SACQUET \\ From the Station de Recherches de Nutrition, Laboratoire de Physiologie de la Nutrition and Laboratoire des \\ Animaux sans Germes, CNRS-INRA-CNRZ, 78350 Jouy-en-Josas, France
}

SUMMARY Bile duct ligation was performed in germ-free and conventional rats in order to study the effects of bile deprivation on the absorption of dietary lipids and the excretion of faecal lipids in the presence or the absence of gastrointestinal flora. The main consequence of bile duct ligation in conventional rats was a decrease of about $50 \%$ in the apparent absorption of dietary lipids (peanut oil). In germ-free rats, absorption decreased by only about $25 \%$. In conventional as well as in germfree controls, faecal lipids were mainly excreted as compounds directly soluble in organic solventsthat is, free fatty acids, triglycerides, partial glycerides, cholesterol, cholesterol esters. Deprivation of bile secretion significantly increased the faecal excretion of 'insoluble' compounds - that is, calcium soaps-both in germ-free and conventional rats. Free fatty acids and sterol esters were the two main classes of soluble faecal lipids both in germ-free and conventional rats deprived of bile secretion. Faecal excretion of triglycerides remained low in germ-free as well as in conventional animals. No significant difference of fatty acid absorption was observed between germ-free and conventional controls. Deprivation of bile secretion resulted in a significant decrease in the absorption of all fatty acids in germ-free as well as in conventional animals. However, the decrease was larger for saturated fatty acids - that is, 16:0 or 18:0 - than for unsaturated fatty acids-that is, $18: 1$ or 18:2. The absorption of all fatty acids, except linoleic acid $(18: 2)$, was significantly lower in conventional rats artificially deprived of bile secretion than in their germ-free counterparts. Evidence was given for a negative digestive balance of stearic acid (18:0) in bile deprived conventional animals. This observation was correlated with a very efficient biohydrogenation of dietary unsaturated fatty acids as revealed by radio gas chromatography of faecal acids in bile deprived conventional rats fed a diet containing $1-{ }^{14} \mathrm{C}$ oleic acid (18:1) as homogeneous triglycerides. Nevertheless, biohydrogenation of unsaturated dietary fatty acids by the gastrointestinal flora was not considered to be the only factor involved in the origin of the differences of fat absorption between bile deprived germfree and conventional animals.

It is now well established that lipid digestion involves three different and coordinated processes: emulsification, hydrolysis of the substrate, and micellar solubilisation of the hydrolysis products in the aqueous medium of the intestinal contents. ${ }^{1}$ In vivo, bile salts are normally implicated in all the steps of lipid digestion and absorption. ${ }^{2}$ In vitro experiments, as well as analysis of intestinal contents in bile fistula man or dog, have shown that hydrolysis of triglycerides may efficiently occur without the help of bile compounds. 34 Even though contrary results have been reported in the rat, 5 it is now generally admitted that micellar solubili-

Received for publication 1 June 1981 sation rather than lipolysis is rate limiting in bile deficiency as an explanation of the decrease of fat absorption. ${ }^{6} \mathrm{Up}$ to the present, all the experiments in that field have been performed with conventional animals. The gastrointestinal tract contains a large bacterial population which influences the digestion and the absorption of almost all nutrients. ${ }^{7}$ It has been clearly demonstrated that bacteria may widely interfere with digestion and absorption of dietary lipids and it has also been shown that the gastrointestinal flora largely modifies the metabolism of bile salts. 89 Consequently, all the studies that have been carried out have systematically discarded the possible interferences between gastro- 
intestinal flora, lipid digestion, and absorption in case of bile deficiency. The main purpose of the present study was (1) to compare the effects of bile deprivation upon the absorption of dietary lipids both in germ-free and conventional rats, and, then, (2) to study the distribution of the different classes of faecal lipids in bile deficiency and in the two types of animals in order to detect an eventual defect of hydrolysis. We also paid attention to the possible bacterial biohydrogenation of dietary unsaturated fatty acids in the different kinds of animals.

\section{Methods}

\section{ANIMALS}

The experiment was performed using two groups of 12 conventional rats and 12 germ-free rats (Fischer strain). Mean body weight at the beginning of the experiment was $290 \pm 9 \mathrm{~g}$. In each group, six animals were operated on and fitted with a bile duct ligation, while six others-or controls-were sham-operated (laparotomy without bile duct ligation). All operations were carried out under general anaesthesia. Germ-free rats were maintained in individual metabolism cages in plastic isolators (Trexler type), whereas conventional animals were placed in individual cages in a traditional animal-house.

DIET

All animals were adapted to the same experimental $\gamma$ ray sterilised diet eight days before surgery. The composition of the diet is shown in Table 1. It contained $10 \%$ lipids (peanut oil) and the fatty acid composition of dietary lipids is given in Table 2. After a 10 day recovery period, animals were submitted to a 10 day experimental period during which the digestibility of the diet was measured. They ingested the same quantity of food (11 g/day) and that level was determined during the recovery period. Diet was offered

Table 1 Composition of experimental diet

\begin{tabular}{ll}
\hline Ingredients & $\mathrm{g} / 100 \mathrm{~g}$ \\
\hline Maize starch & $58 \cdot 6$ \\
Casein & $20 \cdot 8$ \\
Peanut oil + vitamins ADEK & $10 \cdot 0$ \\
Cellulose & $5 \cdot 0$ \\
Vitamin mix & $0 \cdot 8$ \\
Mineral mix & $4 \cdot 5$ \\
Choline & 0.3 \\
\hline
\end{tabular}

Table 2 Fatty acid composition of dietary lipids (\% weight of total fatty acids)

\begin{tabular}{ccccccccccc}
\hline $14: 0$ & $16: 0$ & $16: 1$ & $18: 0$ & $18: 1$ & $18: 2$ & $20: 0$ & $20: 1$ & $22: 0$ & $24: 0$ & Others $^{*}$ \\
\hline 0.1 & 12.6 & 0.1 & 5.6 & 35.2 & 38.6 & 1.6 & 0.8 & 3.1 & 1.3 & 1.0 \\
\hline * Mainly $24: 1$ and & 18.3 & & & & & & &
\end{tabular}

once a day and all faeces were collected every day and stored at $-30^{\circ} \mathrm{C}$ until the end of the experimental period. Urine was absorbed on several layers of filter paper, changed once a day.

\section{EXPERIMENTAL DESIGN}

The criteria used to estimate absorption was the measure of apparent digestibility. The techniques were described by Henry and Rerat 10 and values expressed according to the formula:

$$
\frac{\text { absorbed }}{\text { ingested }} \times 100=\frac{\text { ingested }- \text { excreted in faeces }}{\text { ingested }} \times 100
$$

In order to estimate the possible effect of bile deprivation upon the biohydrogenation of dietary unsaturated fatty acids in conventional animals another experiment was performed with conventional rats. A tracer dose of oleic acid as pure glyceryl trioleate (1-14C oleic acid 0.05 mCi from CEA, F-91 190 Gif-surYvette) was incorporated into an experimental meal prepared with a powdered commercial rodent chow. Faeces were collected to study the distribution of radioactivity among the different molecules of faecal fatty acids using radio gas-chromatography.

\section{ANALYSIS}

Dry matter contents in the diet and faeces were determined after complete dehydration of aliquot samples until constant weight in an oven at $75^{\circ} \mathrm{C}$. Quantitative estimation of organic matters was performed as previously described.11 Total energy contents of faecal and dietary samples were determined using a calorimetric bomb. Total lipids of the diet were extracted using hexane. Total contents of fatty acids in dietary lipids were obtained after saponification with a $10 \%$ alcoholic potassium hydroxide solution in excess.

Faecal lipids were extracted by a two-step procedure in order to separate 'soluble' faecal lipids from 'insoluble' faecal compounds mainly composed of fatty acids precipitated as calcium soaps. 12 Details concerning the technique have been recently described.13 Briefly, lipids and fatty acids were first directly extracted from a known aliquot of dry faecal powder using chloroform-methanol $(2: 1, \mathrm{v} / \mathrm{v})$ as a solvent. They constituted the soluble fraction which was weighed after purification. ${ }^{14}$ Fatty acid contents were gravimetrically determined after saponification as previously reported. The residue from this first extraction, which contained fatty acids precipitated as insoluble soaps, was then submitted to $\mathrm{HCl}$ hydrolysis and free fatty acids extracted using hexane. This fraction was weighed and called insoluble. In the study of radioactivity distribution among faecal fatty acids, the extraction of all fatty acids was performed in a onestep procedure after direct hydrolysis of an aliquot of dry faecal powder. 
Lipid classes from soluble faecal lipid fractions were separated by thin-layer chromatography on silica gel. The solvent system consisted of hexane, diethyl ether, and formic acid (85:20:2 by volume). To study the distribution of faecal lipids among the different classes the spots were charred on the plates as suggested by Fewster et al.15 and the amount of charred material estimated by means of a (Vernon) scanning photodensitometer.

Pure fatty acids resulting from saponification of the different lipid samples 'were methylated in hot methanol-HCl $(97: 3, \mathrm{v} / \mathrm{v})$ for one hour. Analyses of fatty acid methyl esters were performed using a Girdel $\mathrm{FD}_{2}$ gas-liquid chromatograph. Fatty acid separation was made using a stainless steel open tubular (capillary) column (100 m length $\times 0.5 \mathrm{~mm}$ ID). Stationary phase was Carbowax 20M-terephtalic acid. All details of the analytical procedure have been described previously. 13

For radio gas liquid chromatography, pure fatty acids were prepared as previously described. Methyl esters were analysed for mass and radioactivity on the Packard Model 427 gas chromatograph connected with the Packard 894 gas proportional counter. Gas chromatograph was fitted with a stainless steel column $(2 \mathrm{~mm} \times 3 \mathrm{~m})$ coated with $5 \%$ Degs on $80 / 100$ Chromosorb G-DMCS. Mass and radioactivity were simultaneously recorded on a dual-pen recorder (Sefram, France).

\section{Results}

Deprivation of bile secretion first resulted in a significant decrease $(P<0.05)$ in the digestibility of dry matter in conventional rats $(89.3 \pm 0.5 \%$ vs $84.9 \pm 0.5 \%)$, whereas no significant alteration was observed in germfree animals $(87.8 \pm 0.3 \%$ vs $87.6 \pm 0.4 \%)$. Where total dietary energy was concerned no significant difference was observed between germ-free and conventional controls. Digestibility of energy was significantly $(\mathrm{P}<0.05)$ decreased both in germ-free $(90.3 \pm 0.3 \%$ vs $86.3 \pm 0.6 \%)$ and in conventional $(91.4 \pm 0.6 \%$ vs $81 \cdot 3 \pm 0 \cdot 8 \%$ animals. Nevertheless, the decrease was much larger in conventional than in germ-free animals.

The relative proportions of faecal lipids in controls were significantly higher in conventional than in germfree rats (Table 3). Bile duct ligation drastically increased the relative proportions of lipids in faeces (approximately six times more in the two types of animals). Nevertheless, when bile duct ligation was made relative proportions remained lower in germfree than in conventional animals. As shown in Table 3 faecal lipids were mainly excreted as soluble compounds in both groups of animals. When animals were bile-deprived, relative proportions of soluble compounds in faecal lipids largely decreased in germ-free and conventional rats. However, relative proportions
Table 3 Total lipid contents of dry faeces and distribution of faecal lipids between soluble and insoluble lipids*

\begin{tabular}{|c|c|c|c|c|c|}
\hline & \multicolumn{4}{|l|}{ Animals } & \multirow{2}{*}{$\begin{array}{l}\text { Significant } \\
\text { differences } \dagger\end{array}$} \\
\hline & $\begin{array}{l}G F \\
\text { control } \\
(a)\end{array}$ & $\begin{array}{l}G F \\
\text { ligated } \\
(b)\end{array}$ & $\begin{array}{l}C V \\
\text { control } \\
\text { (c) }\end{array}$ & $\begin{array}{l}C V \\
\text { ligated } \\
\text { (d) }\end{array}$ & \\
\hline$\%$ of lipids in faeces & $3 \cdot 7 \pm 0 \cdot 1$ & $22 \cdot 8 \pm 1 \cdot 6$ & $5.4 \pm 0.2$ & $32.6 \pm 0.8$ & $\begin{array}{l}\text { (a) VS (b) } \\
\text { (c) VS (d) } \\
\text { (a) VS (c) } \\
\text { (b) VS (d) }\end{array}$ \\
\hline $\begin{array}{l}\% \text { of total faecal } \\
\text { lipids as soluble } \\
\text { lipids }\end{array}$ & $85 \cdot 8 \pm 2 \cdot 3$ & $71 \cdot 3 \pm 2 \cdot 4$ & $86.6 \pm 1.6$ & $55 \cdot 2 \pm 2 \cdot 7$ & $\begin{array}{l}\text { (a) VS (b) } \\
\text { (c) VS (d) } \\
\text { (b) VS (d) }\end{array}$ \\
\hline
\end{tabular}

* Values are means \pm SEM.

+ At least $\mathrm{P}<0.05$.

of soluble compounds were significantly higher in germ-free bile deprived animals than in their conventional homologues.

As shown in Table 4 no significant difference was observed for the absorption of total dietary lipids between germ-free and conventional controls. The same observation was made for total dietary fatty acids. Bile duct ligation highly decreased the absorption of dietary lipids both in germ-free and conventional animals. However, the effect was much more pronounced in conventional rats than in germ-free rats, as the absorption was significantly larger in the latter. As observed for total lipids, bile duct ligation considerably decreased the absorption of total dietary fatty acids in germ-free and conventional animals, but the effect was larger in conventional than in germ-free rats. Furthermore, it was noticed that bile deprivation decreased the absorption of total lipids more efficiently than that of total fatty acids, particularly in conventional animals.

The fatty acid composition of 'soluble' and 'insoluble' faecal lipid fractions is shown in Table 5. Where soluble lipids are concerned it can be seen that no significant differences were observed between germ-

Table 4 Apparent digestibility of total dietary lipids and total dietary fatty acids*

\begin{tabular}{|c|c|c|c|c|c|}
\hline & \multicolumn{4}{|l|}{ Animals } & \multirow{2}{*}{$\begin{array}{l}\text { Significant } \\
\text { differences }\end{array}$} \\
\hline & $\begin{array}{l}G F \\
\text { control } \\
\text { (a) }\end{array}$ & $\begin{array}{l}\text { GF } \\
\text { ligated } \\
\text { (b) }\end{array}$ & $\begin{array}{l}C V \\
\text { control } \\
(c)\end{array}$ & $\begin{array}{l}C V \\
\text { ligated } \\
\text { (d) }\end{array}$ & \\
\hline $\begin{array}{l}\text { Apparent } \\
\text { digestibility of total } \\
\text { dietary lipids (\%) }\end{array}$ & $95 \cdot 4 \pm 0 \cdot 2$ & $70 \cdot 3 \pm 2 \cdot 2$ & $94.5 \pm 0.4$ & $46 \cdot 3 \pm 2 \cdot 5$ & $\begin{array}{l}\text { (a) VS (b) } \\
\text { (c) VS (d) } \\
\text { (b) VS (d) }\end{array}$ \\
\hline $\begin{array}{l}\text { Apparent } \\
\text { digestibility of total } \\
\text { dietary fatty acids }(\%)\end{array}$ & $97 \cdot 5 \pm 0 \cdot 2$ & $78 \cdot 8 \pm 1 \cdot 3$ & $96 \cdot 5 \pm 0.4$ & $56 \cdot 1 \pm 2 \cdot 7$ & $\begin{array}{l}\text { (a) VS (b) } \\
\text { (c) VS (d) } \\
\text { (b) VS (d) }\end{array}$ \\
\hline
\end{tabular}


Table 5 Fatty acid compositions of faecal soluble (SFL) and insoluble (IFL) lipids (weight \% of total fatty acids)*

\begin{tabular}{|c|c|c|c|c|c|c|c|c|c|c|c|}
\hline Faecal lipids and animals & $14: 0$ & $16: 0$ & $16: I$ & $18: 0$ & $18: 1$ & $18: 2$ & $20: 0$ & $20: 1$ & $22: 0$ & $24: 0$ & Endogenous \\
\hline \multicolumn{12}{|l|}{ SFL } \\
\hline GF control (a) & $1 \cdot 0$ & $23 \cdot 6$ & 3.0 & $15 \cdot 4$ & $15 \cdot 9$ & $4 \cdot 2$ & $4 \cdot 6$ & $8 \cdot 2$ & $10 \cdot 2$ & $8 \cdot 5$ & $5 \cdot 4$ \\
\hline GF ligated (b) & $0 \cdot 4$ & $17 \cdot 5$ & 0.4 & $7 \cdot 2$ & $43 \cdot 7$ & $12 \cdot 1$ & $2 \cdot 6$ & $5 \cdot 7$ & $6 \cdot 0$ & $2 \cdot 6$ & 1.8 \\
\hline CV control (c) & 1.9 & $23 \cdot 4$ & 0.4 & $15 \cdot 3$ & $14 \cdot 4$ & $5 \cdot 7$ & $6 \cdot 0$ & $4 \cdot 0$ & $10 \cdot 3$ & $7 \cdot 5$ & $11 \cdot 2$ \\
\hline CV ligated (d) & 0.4 & 13.9 & $0 \cdot 4$ & $12 \cdot 6$ & $39 \cdot 7$ & $9 \cdot 5$ & $1 \cdot 8$ & $4 \cdot 4$ & $3 \cdot 4$ & $7 \cdot 9$ & $6 \cdot 0$ \\
\hline Significant differences & & $\begin{array}{l}\text { (a) VS } \\
\text { (c) VS }\end{array}$ & & $\begin{array}{l}\text { (a) VS (b) } \\
\text { (b) VS (d) }\end{array}$ & $\begin{array}{l}\text { (a) VS (b) } \\
\text { (c) VS (d) }\end{array}$ & (a) VS (b) & (c) VS (d) & NS & $\begin{array}{l}\text { (a) VS (b) } \\
\text { (c) VS (d) }\end{array}$ & (a) VS (b) & $\begin{array}{l}\text { (a) VS (b) } \\
\text { (a) VS (c) } \\
\text { (c) VS (d) } \\
\text { (b) VS (d) }\end{array}$ \\
\hline \multicolumn{12}{|l|}{ IFL } \\
\hline GF control (a) & $1 \cdot 5$ & $30 \cdot 4$ & $2 \cdot 2$ & $13 \cdot 5$ & $14 \cdot 1$ & $4 \cdot 9$ & $2 \cdot 8$ & $3 \cdot 1$ & $8 \cdot 2$ & $9 \cdot 9$ & $9 \cdot 4$ \\
\hline GF ligated (b) & 0.5 & $31 \cdot 0$ & 0.6 & $20 \cdot 0$ & $10 \cdot 5$ & $2 \cdot 5$ & 6.9 & $2 \cdot 0$ & $16 \cdot 1$ & 6.9 & $3 \cdot 0$ \\
\hline CV control (c) & 0.6 & $15 \cdot 7$ & $0 \cdot 4$ & $14 \cdot 8$ & $10 \cdot 4$ & $3 \cdot 5$ & $8 \cdot 4$ & $4 \cdot 0$ & $17 \cdot 2$ & $14 \cdot 5$ & $10 \cdot 5$ \\
\hline CV ligated (d) & $0 \cdot 1$ & $23 \cdot 8$ & 0.3 & $37 \cdot 7$ & 13.0 & $1 \cdot 8$ & $4 \cdot 8$ & $1 \cdot 2$ & $7 \cdot 9$ & $3 \cdot 2$ & $6 \cdot 2$ \\
\hline Significant differences & & $\begin{array}{l}\text { (a) VS } \\
\text { (c) VS } \\
\text { (b) V }\end{array}$ & & $\begin{array}{l}\text { (c) VS (d) } \\
\text { (b) VS (d) }\end{array}$ & $\begin{array}{l}\text { (a) VS (b) } \\
\text { (a) VS (c) }\end{array}$ & NS & $\begin{array}{l}\text { (a) VS (b) } \\
\text { (a) VS (c) } \\
\text { (c) VS (d) }\end{array}$ & NS & $\begin{array}{l}\text { (a) VS (b) } \\
\text { (c) VS (d) } \\
\text { (a) VS (c) } \\
\text { (b) VS (d) }\end{array}$ & $\begin{array}{l}\text { (c) VS (d) } \\
\text { (a) VS (c) } \\
\text { (b) VS (d) }\end{array}$ & $\begin{array}{l}\text { (a) VS (b) } \\
\text { (c) VS (d) }\end{array}$ \\
\hline
\end{tabular}

* Only mean values are reported

†At least $\mathbf{P}<0.05$.

free and conventional controls except for exclusively endogenous fatty acid proportions: these were twice as high in conventional controls as in germ-free animals. This was mainly correlated with the faecal excretion of bacterial fatty acids (odd-numbered and branched-chain fatty acids); this did not occur in the faecal lipids from germ-free animals. Endogenous fatty acids from germ-free rats were mainly long-chain polyunsaturated fatty acids. Deprivation of bile secretion resulted in considerable changes in the fatty acid compositions of soluble faecal lipids. In germ-free animals changes were mainly characterised by a considerable decrease in saturated and endogenous fatty acid contents, whereas oleic acid (18:1) and linoleic acid (18:2) contents significantly increased. In conventional animals the same general effects were noticed but different values were observed when compared with bile deprived germ-free animals. Where insoluble faecal lipids were concerned, it was noticed that fatty acid composition did not greatly differ from that of soluble faecal lipids in germ-free controls. This was not the case for conventional controls where larger contents of very long chain saturated fatty acids $(>18: 0)$ and smaller contents of palmitic (16:0) were observed in insoluble faecal lipids. Thus - and contrary to results reported for soluble faecal lipids-fatty acid composition of insoluble lipids largely differed between germ-free and conventional animals. When bile deprivation occurred changes were observed both in germ-free and conventional rats. In germ-free animals changes were mainly characterised by an increase in long chain fatty acid $(>18)$ contents and a decrease in oleic acid and endogenous fatty acid contents. In conventional rats changes were essentially characterised by a significant increase in palmitic acid (16:0) and stearic acid (18:0) contents, whereas all the other fatty acid contents were maintained or significantly decreased.

Analysis of soluble faecal lipids by thin-layer chromatography (Fig. 1) revealed that, in germ-free controls, free fatty acids, sterol esters + non-polar lipids, and cholesterol were the three main components. Triglycerides, phospholipids, and partial glycerides were minor components. In conventional controls supplementary and undetermined compounds were also observed but triglycerides and partial glycerides remained minor components. When germ-free and conventional animals were bile-deprived free fatty acids and sterol esters + non polar lipids were the two major classes of lipids, while triglycerides and partial glycerides remained minor components of soluble faecal lipids both in germ-free and conventional animals.

As shown in Table 6 absorption of the four main dietary fatty acids did not significantly differ between germ-free and conventional controls. In all cases it exceeded $90 \%$ of the fed amount. When animals were artificially bile deprived, absorption decreases were observed for all fatty acids in both germ-free and conventional animals. Results were dependent both on the molecular characteristics of fed fatty acids and on the occurrence of a gastrointestinal flora. Only slight decreases were observed for linoleic acid (18:2) absorption and no significant differences appeared between bile deprived germ-free and conventional animals. As compared with linoleic acid (18:2), decreases were larger for oleic acid $(18: 1)$ and evidence 


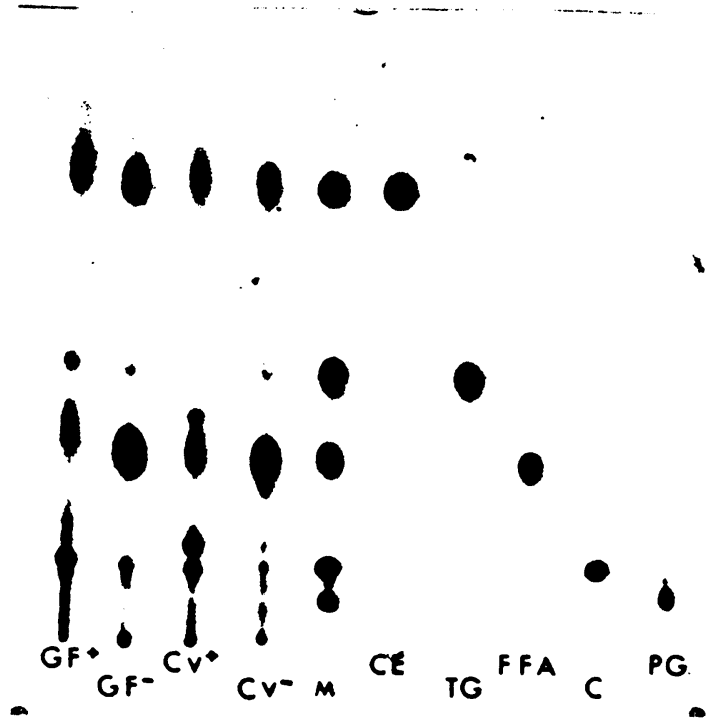

Fig. 1 Thin layer chromatography of faecal soluble lipids (SFL) and photodensitomeric scan (right) from germ-free and conventional animals deprived $(-)$ or not deprived $(+)$ of bile secretion. PG: partial glycerides. C: cholesterol. FFA: free fatty acids. TG: triglycerides. CE: sterols esters (+ other non-polar lipids). PL: phospholipids and non-lipid contaminants. M: standard mixture. (?): non-determined compounds. For experimental samples $70 \mu \mathrm{g} S F L$ were applied in one single spot. For analytical procedure see Methods section.

Table 6 Apparent digestibility $(\%)$ of four main dietary fatty acids*

\begin{tabular}{clllll}
\hline Fatty acids & $\begin{array}{l}G F \\
\text { control } \\
(a)\end{array}$ & $\begin{array}{l}G F \\
\text { ligated } \\
(b)\end{array}$ & $\begin{array}{l}C V \\
\text { control } \\
(c)\end{array}$ & $\begin{array}{l}C V \\
\text { ligated } \\
(c)\end{array}$ & $\begin{array}{l}\text { Significant } \\
\text { differencest }\end{array}$ \\
\hline $16: 0$ & $95.1 \pm 0.8$ & $60.2 \pm 2.0$ & $94.9 \pm 0.7$ & $34.3 \pm 1.2$ & $\begin{array}{l}\text { (a) VS (b) } \\
\text { (c) VS (d) } \\
\text { (b) VS (d) }\end{array}$ \\
$18: 0$ & $93.8 \pm 1.1$ & $51.7 \pm 1.8$ & $90.3 \pm 1.2$ & $-97.3 \pm 2.3 \pm \begin{array}{l}\text { (a) VS (b) } \\
\text { (c) VS (d) } \\
\text { (b) VS (d) }\end{array}$ \\
$18: 1$ & $98.9 \pm 0.7$ & $82.1 \pm 1.2$ & $98.7 \pm 1.6$ & $67.1 \pm 1.9$ & $\begin{array}{l}\text { (a) VS (b) } \\
\text { (c) VS (d) } \\
\text { (b) VS (d) }\end{array}$ \\
$18: 2$ & $99.7 \pm 0.3$ & $95.6 \pm 0.5$ & $99.5 \pm 0.9$ & $93.6 \pm 1.0$ & $\begin{array}{l}\text { (a) VS (b) } \\
\text { (c) VS (d) }\end{array}$ \\
\hline
\end{tabular}

*Values are means \pm SEM.

+ At least $P<0.05$.

$\ddagger$ Negative balance.

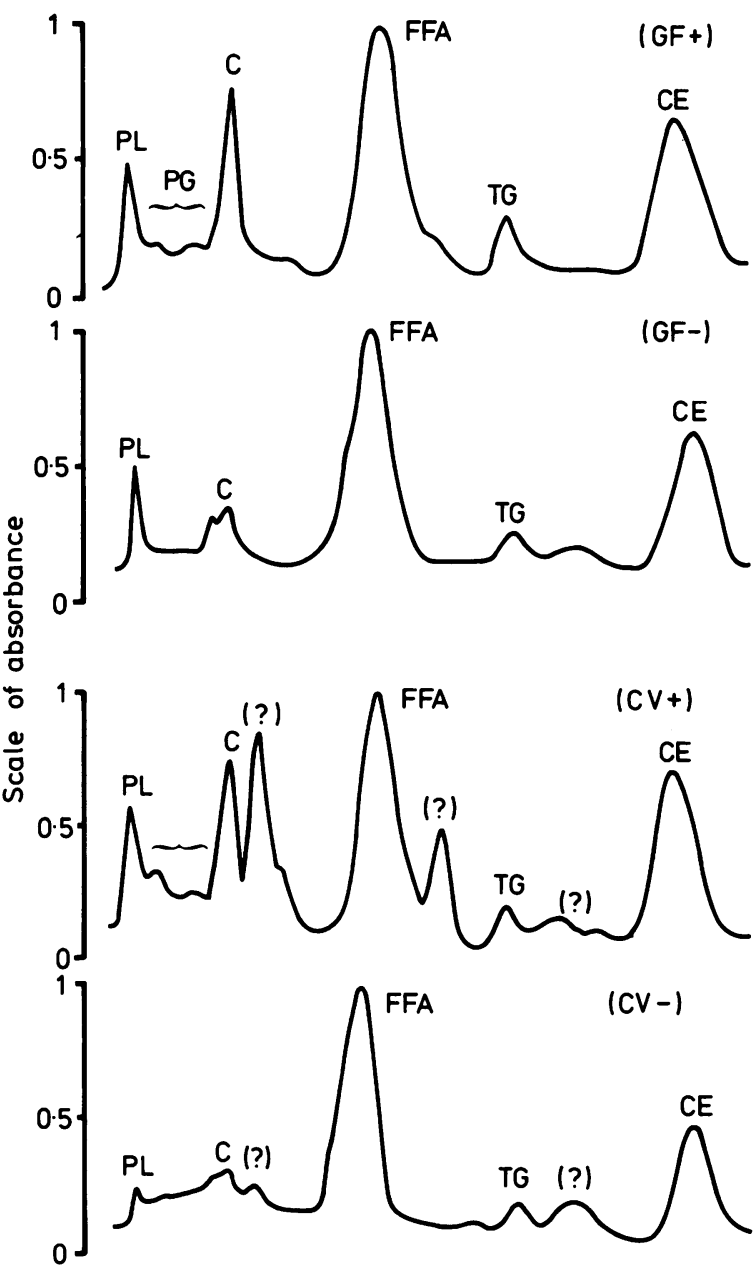

was given for a significant effect of the gastrointestinal flora, as decrease of apparent absorption was calculated to be approximately $17 \%$ in germ-free animals $v$ s. $32 \%$ in conventional ones. However, the greatest effects of bile deprivation were observed for saturated fatty acids and were significantly enhanced by the occurrence of a flora in the gastrointestinal tract. The absorption of palmitic acid (16:0) was lowered by more than $35 \%$ in germ-free rats and by more than $60 \%$ in conventional rats. Where stearic acid (18:0) absorption was concerned, it decreased by $45 \%$ in bile deprived germ-free animals, whereas in conventional rats a negative digestive balance was shown, as faecal excretion was about twice as large as dietary supply.

As shown in Table 7 large differences were observed when comparing the contribution of each fatty acid to the overall increase in faecal excretion of total fatty acids. When bile deprived germ-free animals were 
Table 7 Faecal excretion of fatty acids related to theoretical intake of $10000 \mathrm{mg}$ fatty acids and contribution of each type of molecula to increase of total faecal excretion of fatty acids $(\%)$.

\begin{tabular}{|c|c|c|c|c|c|c|c|}
\hline Animals & Intake & Excretion & $16: 0$ & $18: 0$ & $18: 1$ & $18: 2$ & Others* \\
\hline GF control $(\mathrm{GF}+)(\mathrm{mg})$ & 10000 & 250 & 62 & 35 & 39 & 11 & 103 \\
\hline GF ligated $(\mathrm{GF}-)^{\prime}(\mathrm{mg})$ & 10000 & 2120 & 502 & 270 & 630 & 170 & 548 \\
\hline $\mathrm{CV}$ control $(\mathrm{CV}+)(\mathrm{mg})$ & 10000 & 350 & 64 & 54 & 46 & 19 & 167 \\
\hline $\mathrm{CV}$ ligated $(\mathrm{CV}-)(\mathrm{mg})$ & 10000 & 4390 & 828 & 1105 & 1158 & 247 & 1052 \\
\hline \multirow[t]{2}{*}{$(\mathrm{GF}-)-(\mathrm{GF}+)(\mathrm{mg})$} & - & +1870 & +440 & +235 & 591 & +159 & 445 \\
\hline & & & $(23.5) \dagger$ & $(12 \cdot 6)$ & $(31 \cdot 6)$ & $(8 \cdot 5)$ & $(23 \cdot 8)$ \\
\hline \multirow[t]{2}{*}{$(\mathrm{CV}-)-(\mathrm{CV}+)(\mathrm{mg})$} & - & +4040 & 764 & +1051 & .1112 & +228 & 885 \\
\hline & & & $(18.9)$ & $(26 \cdot 0)$ & $(27 \cdot 5)$ & $(5 \cdot 6)$ & $(21 \cdot 9)$ \\
\hline \multirow[t]{2}{*}{$(\mathrm{CV}-)-(\mathrm{GF}-)(\mathrm{mg})$} & - & +2270 & +326 & +835 & +528 & +77 & +504 \\
\hline & & & $(14 \cdot 3)$ & $(36 \cdot 8)$ & $(23 \cdot 2)$ & $(3 \cdot 4)$ & $(22 \cdot 2)$ \\
\hline
\end{tabular}

* Long-chain fatty acids ( $>\mathrm{C} 18)$ and endogenous.

+ Respective contribution of each fatty acid to the increase of total faecal excretion of fatty acids.

compared with germ-free controls it was seen that the largest increase in fatty acid excretion was contributed by oleic acid (18:1) excretion - over 30\%-and then by palmitic acid (16:0) and long chain and endogenous fatty acids $-20-25 \%$, while stearic acid (18:0) and linoleic acid (18:2) contributed only a small proportion $(8-12 \%)$. When bile deprived conventional animals were compared with conventional controls it was observed that oleic acid $(18: 1)$ and stearic acid $(18: 0)$ contributed approximately the same percentage to the increase of faecal fatty acid excretion (26-28\%). When bile deprived germ-free and conventional animals were compared it was shown that the twice as large faecal excretion of fatty acids that was observed in conven-
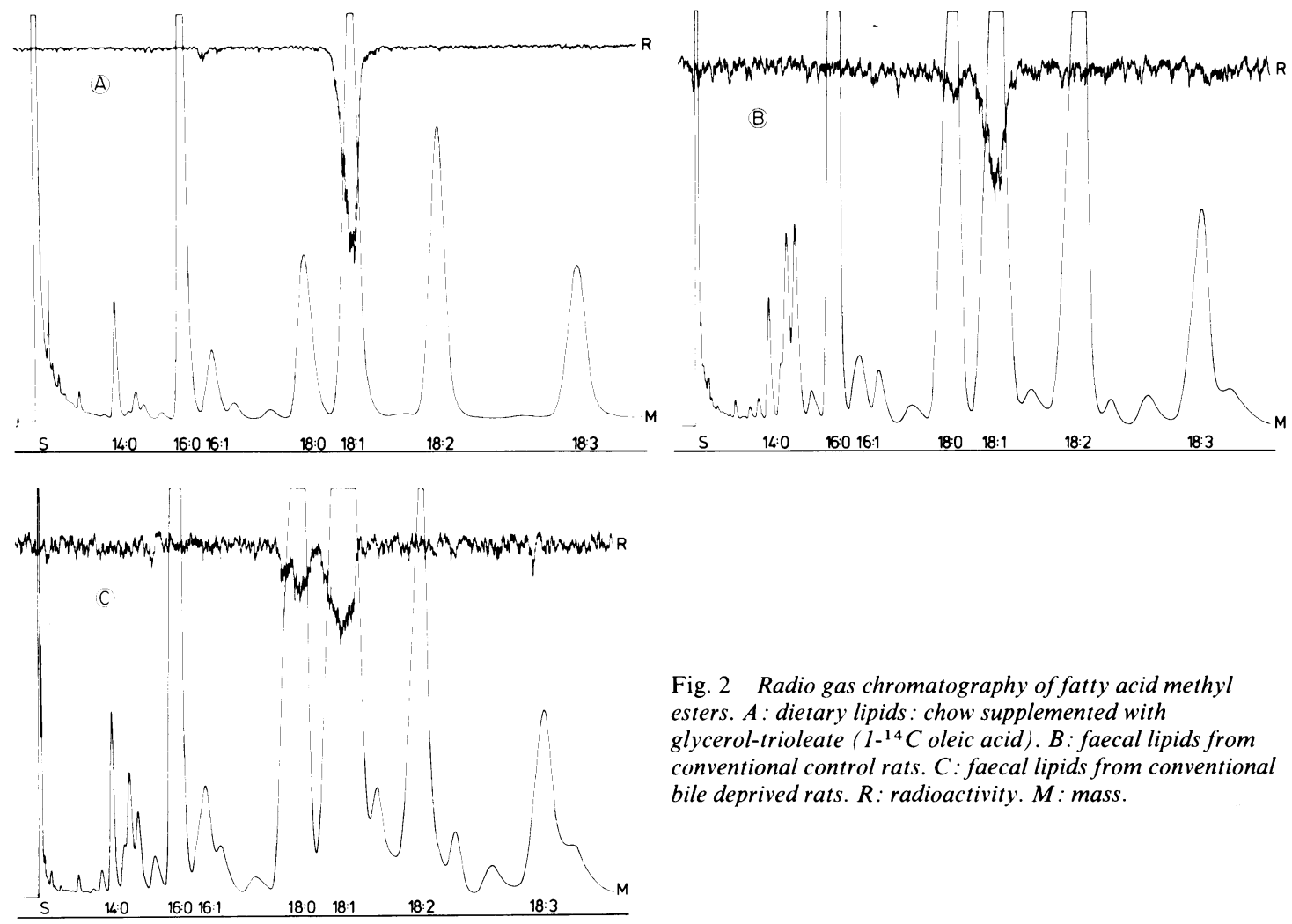

Fig. 2 Radio gas chromatography of fatty acid methyl esters. A : dietary lipids: chow supplemented with glycerol-trioleate $\left(1-{ }^{14} \mathrm{C}\right.$ oleic acid). $B$ : faecal lipids from conventional control rats. $C$ : faecal lipids from conventional bile deprived rats. $R$ : radioactivity. $M$ : mass. 
tional animals was differently related with the increase in the faecal excretion of each fatty acid; stearic acid (18:0), oleic acid (18:1), and long-chain fatty acids represented more than $80 \%$ of the total increase, whereas linoleic acid $(18: 2 ; 38.6 \%$ of the dietary fattyacids) contributed only $3.5 \%$ to the increased faecal excretion of fatty acids.

When conventional rats were fed the chow diet supplemented with glycerol-trioleate $\left(1-{ }^{14} \mathrm{C}\right.$ oleic acid), radioactivity was found both in faecal stearic (18:0) and oleic acid (18:1) (Fig. 2). Nevertheless, in shamoperated conventional rats stearic acid radioactivity represented only $10 \%$ of the total faecal radioactivity, whereas in the bile deprived homologous rats it represented $30 \%$.

\section{Discussion}

The results presented in this study show that the gastrointestinal flora does not normally interfere with the absorption of peanut oil. This dietary fat is a highly unsaturated oil, as it generally contains more than $75 \%$ mono and polyunsaturated fatty acids. It has been observed previously that the gastrointestinal flora does not alter the intestinal absorption of unsaturated fatty acids. ${ }^{8}$ On the contrary, saturated fatty acids such as palmitic and stearic acid (16:0 and 18:0) have been reported to be better absorbed in germ-free than in conventional rats when they are esterified in highly saturated fats. ${ }^{8}$ It has also been shown that the intestinal absorption of saturated fatty acids is dependent on the unsaturated/saturated fatty acid ratio in the diet and decreases when this ratio decreases. ${ }^{16}$ In peanut oil this ratio is very high and absorption of palmitic acid exceeds $95 \%$, whereas in conventional rats it was previously reported to be as low as $68 \%$ (vs $80 \%$ in germ-free animals) when saturated fatty acids represented more than $65 \%$ of total dietary fatty acids. ${ }^{8}$ This illustrates once again the fact that unsaturated dietary fatty acids promote the absorption of saturated ones. This effect has been correlated with a better micellar solubilisation of saturated fatty acids and with an effective protection against precipitation as insoluble compounds like calcium soaps. ${ }^{17}$ At present, it is confirmed that the gastrointestinal flora may exhibit its negative effect upon the absorption of saturated fatty acid only when they are included in high concentrations in the diet.

The large difference of fat absorption observed between bile deprived germ-free and conventional animals was unexpected. Moreover, it was confirmed by the decrease in total energy digestive balance. Results clearly show that the gastrointestinal flora may interfere with absorption otherwise than by bile salt metabolism, as previously reported. 18

The TLC data show that hydrolysis of dietary triglycerides may occur in vivo without the help of bile secretion. It is clearly established that the gastrointestinal flora is not apparently involved in the origin of the high level of free fatty acids observed in faecal lipids from bile deprived animals, as it was observed in both germ-free and conventional rats. Thus, it is confirmed that defective micellar solubilisation rather than impaired lipolysis is responsible for the steatorrhoea observed in bile deficiency.

The occurrence of large amounts of sterol esters and other non-polar lipids in bile deficient animals can be correlated with the fact that cholesterol ester hydrolase (EC 3.1.1.13) requires bile salts for its own activity and that unhydrolysed esters cannot be efficiently absorbed.619 This appears to be unrelated to the gastrointestinal flora as it was observed both in germfree and conventional animals. It can also be correlated with the fact that non-polar lipid compounds such as liposoluble vitamins demand a micellar solubilisation for absorption. ${ }^{20}$

Results obtained from radio gas-chromatography of faecal fatty acids show that about $30 \%$ of non-absorbed oleic acid (18:1) is transformed into stearic acid (18:0) in bile deprived conventional rats. Such a biohydrogenation related to the large amount of non-absorbed oleic acid in faeces could easily explain the negative digestive balance observed for stearic acid in bile deprived conventional rats. However, bacterial biohydrogenation, which is obviously stimulated in bile deficiency, cannot be the only factor involved in the aetiology of the greater steatorrhoea observed in conventional bile deprived animals, as increase in the faecal excretion of stearic acid represents only $26 \%$ of the total increase in faecal fatty acids observed when compared with conventional controls. Although we have not investigated the possible biohydrogenation of linoleic acid (18:2) into monounsaturated fatty acid, this hypothesis cannot be discarded. It might occur and artificially increase the intestinal content of 18:1, which was shown to be less well absorbed than linoleic acid in bile deprived germ-free animals. As shown in Table 7, even if all supplementary faecal 18:0 and 18:1 were derived from biohydrogenation in bile deprived conventional animals as compared with germ-free homologues, this could explain only $60 \%$ of the increase, as palmitic acid absorption, for instance, also decreased without any large dietary supply of palmitoleic acid (16:1).

Increase of unsaturated fatty acid biohydrogenation might also be correlated with changes in the microbial ecology of the gastrointestinal tract in the bile deprived conventional rat. Bacterial biohydrogenation could occur in the distal part of the digestive tract far from the main sites of fatty acid absorption and thus not really interfere with absorption.

Results mainly suggest that conditions of absorption of monounsaturated and saturated fatty acids are 
better in bile deprived germ-free animals than in their conventional homologues. Where this is concerned it is interesting to note that $45 \%$ of faecal fats were excreted as 'insoluble' compounds such as calcium soaps in bile deprived conventional animals, whereas they represented only $28 \%$ in germ-free homologues. No difference was observed between controls. This higher level of intestinal synthesis of non-absorbable compounds could-in addition to biohydrogenation-account for a large part of the differences observed between the two types of animals. It has been reported previously that faecal excretion of fatty acid insoluble by-products such as calcium complexes is larger in conventional than in germ-free rats when they receive saturated dietary fats. ${ }^{8}$ As a dietary supply of sodium taurocholate considerably decreases the faecal excretion of insoluble complexes in conventional animals, this observation was previously related to the fact that the intestinal content of bile salts is two to three times larger in the germ-free rat. ${ }^{18}$ Present results show that other factors may also be involved at this level and suggest that germ-free animals may possess other physiological characteristics which promote the absorption of the products of lipolysis. This could be investigated at the level of micellar solubilisation but could be also correlated with other known factors such as transit rate or mineral absorption. ${ }^{7}$

Finally, it is also tempting to relate our data to the alterations occurring at the level of the bacterial population in the conventional animals when they are submitted to bile deprivation. In vitro studies have shown that many intestinal bacteria are very sensitive to bile acids such as cholic and deoxycholic acids. ${ }^{21}$ A large bacterial multiplication through the loss of the 'antiseptic' effect of bile could, thus, be evoked as a factor involved by undetermined mechanisms in the large increase of faecal loss of energy and lipids. Unfortunately, data collected in vitro do not apparently correlate with data collected in vivo. For instance, it has been clearly shown that bile deprivation does not induce any significant proliferation of bacteria in the gastrointestinal tract of the rat; only slight selective alterations do appear in the composition of the flora at the different levels of the digestive tract.22 Conversely, it must be remembered that bile acids may also act in vitro, but also in vivo, as growth factor versus some bacterial strains. 2223 Consequently, these contradictory results do not authorise any definitive speculation about this particular point.

\section{References}

1Friedman HI, Nylund B. Intestinal fat digestion, absorption and transport. A review. Am J Clin Nut 1980; 33:1108-39.

2Borgström B. In : Fat digestion and absorption. Intestinal absorption. Smyth, DH ed. Biomembranes, London: Plenum Press 1974: vol. 4B: 555-620.

3Porter HP, Saunders DR, Tytqat G, Brunser O, Rubin E. Fat absorption in bile fistula man. A morphological and biochemical study. Gastroenterology 1971; 60:1008-19.

${ }_{4}^{4}$ Knoebel LK, Ryan JM. Digestion and mucosal absorption of fat in normal and bile-deficient dogs. Am J Physiol 1963: 204:509-14.

${ }^{5}$ Cesano L, Dawson AM. Absorption of ${ }^{14} \mathrm{C}$ triolein in the bile fistula rat. Proc Soc Exp Biol Med 1966; 122:96-9.

${ }^{6}$ Holt PR. The roles of bile acids during the process of normal fat and cholesterol absorption. Arch Intern Med 1972; 130:574-83.

${ }^{7}$ Combe E, Demarne Y, Gueguen L, Ivorec-Szylit O, Meslin JC, Sacquet E. Some aspects of the relationships between gastro-intestinal flora and host nutrition. World Rev Nutr Diet 1976; 24:1-57.

${ }^{8}$ Demarne Y, Sacquet E, Flanzy J, Garnier H, François AC. Utilisation digestive apparente des acides gras chez le rat axénique et le rat holoxénique. Ann Biol Anim Biochim Biophys 1970; 10:369-84.

${ }^{9}$ Van Heijenoort Y, Sacquet E, Raibaud P, Demarne Y, Mathys C. Action de la flore microbienne sur le contenu de l'intestin grêle du rat en acides biliaires. $C R$ Acad Sci(D) Paris 1972; 275:271-4.

${ }^{10}$ Henry Y, Rérat A. Utilisation des pommes de terre deshydratées et fraîches dans l'alimentation du porc en croissance en comparison avec l'orge. Ann Zootech 1966; 15:231-51.

${ }^{11}$ Corring T, Moreau C, Ducluzeau R. Comparative apparent digestibility of casein in holoxenic, axenic and Clostridium bifermentus mono-associated rats. Am J Clin Nutr 1979; 32:1231-7.

${ }^{12}$ Fakambi L, Flanzy J, François AC. Compétition 'in vivo' entre acides gras et phosphore pour la formation de composés insolubles de calcium. C R Acad Sci(D) Paris 1969; 269:2233-5.

${ }^{13}$ Demarne Y, Sacquet E, Lecourtier MJ, Flanzy J. Comparative study of endogenous fecal fatty acids in germ-free and conventional rats. Am J Clin Nutr 1979; 32:2027-32.

${ }^{14}$ Folch J, Lees M, Sloane-Stanley GH. A simple method for the isolation and purification of total lipids from tissues. J Biol Chem 1957; 226 :497-509.

15Fewster ME, Burns BJ, Mead JF. Quantitative densitometric thin-layer chromatography of lipids using copper acetate reagent. J Chromatogr 1969; 43:120-6.

16Thieulin C. Les divers facteurs influant sur l'utilisation digestive des matières grasses. Ann Nutr Alim 1968; 22:245-58.

${ }^{17}$ Hofmann AF. Further studies on the intraaluminal phase of fat digestion: factors influencing the behaviour of fatty acids in bile-salt solutions. Proc VIth Congress of Nutrition $1963 ; 501$.

18Demarne Y, Sacquet E, Van Heijenoort Y, Mathis C. Influence d'une supplémentation de la ration en sels biliaires conjugués sur l'équipement en acides biliaires du rat. Modification de l'absorption apparente des acides gras. Ann Biol Anim Biochim Biophys 1974; 14:239-50.

19 Vahouny GV, Treadwell CR. Absolute requirement of free sterol for absorption by rat intestinal mucosa. Proc Soc Exp Biol Med 1964; 16:496.

${ }^{20} \mathrm{Gallo}$-Torres HE. Obligatory role of bile for the intestinal 
absorption of vitamin E. Lipids 1970; 5:379-84.

${ }^{21}$ Floch MH, Gershengoren W, Elliott S, Spiro HM. Bile acid inhibition of the intestinal microflora. A function for simple bile acids? Gastroenterology 1971; 61 :228-33.

${ }^{22}$ Sacquet E, Raibaud P, Garnier J. Etude comparée de la microflore de l'estomac, de l'intestin grêle et du caecum du rat 'holoxénique' (conventionnel) et de ses modifications à la suite de diverses interventions chirurgicales: anse aveugle jéjunale, déviations biliaires. Ann Inst Pasteur 1971; 120:501-24.

${ }^{23}$ Graber CD, O'Neal RM, Rabin ER. Effect of high fat diets on intestinal microflora and serum cholesterol in rats. J Bacteriol 1965;89:47-51. 